\title{
PENGARUH PENGGUNAAN JENIS GULA PADA MINUMAN COKELAT TERHADAP TINGKAT KESUKAAN PANELIS
}

\author{
Sri Wijanarti ${ }^{1 *}$, Iman Sabarisman ${ }^{2)}$, Ika Restu Revulaningtyas ${ }^{3)}$, Anjar Ruspita Sari ${ }^{4)}$ \\ 1,2,3,4 Program Studi Agroindustri/Departemen Teknologi Hayati dan Veteriner/Sekolah \\ Vokasi, Universitas Gadjah Mada, Indonesia \\ Email: sriwijanarti@ugm.ac.id ${ }^{1)^{*}}$
}

\begin{abstract}
ABSTRAK
Minuman coklat adalah salah satu produk diversifikasi cokelat yang sangat disukai oleh masyarakat. Hasil servei pada 30 orang panelis menunjukkan bahwa karakteristik sensoris yang paling menentukan bagi produk minuman cokelat adalah rasa. Tingkat rasa manis dan rasa pahit yang tepat menjadi penentu tingkat kesukaan panelis. Penggunaan jenis gula yang berbeda dapat menghasilkan karakteristik sensoris minuman cokelat yang berbeda pula sehingga mempengaruhi tingkat kesukaan konsumen. Tujuan penelitian ini adalah untuk mengetahui pengaruh penggunaan jenis gula pada tingkat kesukaan panelis.

Pada penelitian ini dilakukan pembuatan minuman cokelat menggunakan 2 (dua) jenis gula yang berbeda, yaitu gula pasir dan gula semut. Sebanyak 15 orang panelis diminta untuk memilih salah satu diantara dua formula berdasarkan tingkat kesukaannya terhadap rasa manis, rasa pahit, rasa cokelat, rasa gurih, dan rasa keseluruhan.

Hasil menunjukkan bahwa penggunaan gula pasir menghasilkan minuman cokelat dengan karakter manis lebih tinggi sehingga sensasi rasa pahit menurun. Hasil secara keseluruhan menunjukkan bahwa $60 \%$ panelis menyukai minuman cokelat yang dibuat menggunakan gula pasir. Penggunaan gula pasir pada pembuatan minuman coklat lebih ekonomis dan lebih disukai panelis.
\end{abstract}

Keywords: kesukaan, panelis, sensoris, gula pasir, gula semut

\section{PENDAHULUAN}

Minuman coklat adalah salah satu produk pangan olahan kakao. Produk ini dibuat dari bubuk coklat yang dipadukan dengan bahan lain seperti gula, susu, perasa dan lain-lain. Minuman coklat merupakan suatu suspensi di mana terdapat padatan berupa bubuk coklat sebagai "fase terdispersi" dan air sebagai "fase pendispersi". Perkembangan produk-produk minuman coklat sangat pesat. Hal ini ditandai dengan munculnya berbagai merk minuman coklat saat ini.

Minuman coklat disukai karena memiliki rasa yang lezat dan efek kesehatan yang baik.
Kandungan flavonoid, terutama jenis flavan3-ol, sangat baik bagi kardiovaskuler. Kandungan antioksidan dalam coklat juga dapat mencegah inflamasi pembuluh darah sehingga menurunkan resiko aterosklerosis. Konsumsi coklat juga dapat menyebabkan peningkatan NO dalam darah sehingga meningkatkan fungsi endotel dan membantu menurunkan tekanan darah (Surja dkk, 2010). Selain itu, coklat dapat menurunkan kadar koleserol di dalam tubuh dan sebagai anti depresan. (Gunawan,1999).

Rasa dan manfaat kesehatan merupakan atribut mutu yang paling penting pada 
produk minuman coklat, atribut selanjutnya adalah warna, aroma, homogenitas, higenitas, harga, kemasan, dan daya tahan (Apriyanti, 2016). Rasa minuman coklat dihasilkan oleh perpaduan antara bahan-bahan pembuatannya. Atribut sensoris pada minuman coklat antara lain rasa manis, rasa pahit, rasa coklat, rasa gurih, dan keseluruhan.

Minuman coklat yang disukai konsumen adalah yang memiliki perpaduan rasa manis dan pahit yang tepat. Rasa manis yang terlalu dominan justru menurunkan kesukaan konsumen (Butar, 2011). Rasa manis diperoleh dari gula yang digunakan. Gula memiliki karakteristik dan tingkat kemanisan yang berbeda-beda. Dalam pembuatan minuman, ada beberapa jenis gula berdasarkan bentuk fisik diantaranya gula pasir ialah gula yang dihasilkan dari tebu atau bid (sukrosa), mempunyai kristal yang besar, derajat kemanisan 100\% (Cooper et al, 2008). Adapula gula jawa atau gula kelapa. Gula kelapa diperoleh dari nira kelapa yang dididihkan hingga kadar air tertentu kemudian dicetak. Gula kelapa butiran dibuat dari nira kelapa yang dididihkan hingga dapat dikristalkan atau yang sering disebut juga sebagai gula semut.

Gula pasir memiliki tingkat rasa manis yang tinggi dibandingkan gula kelapa namun tidak memberikan sensasi rasa gurih. Sedangkan gula kelapa pada minuman coklat dapat menutup (suppress) rasa coklat memberikan sensasi rasa gurih. Dari sisi kesehatan, gula pasir memiliki indeks glikemiks yang lebih tinggi yaitu 60 dibandingkan gula kelapa yaitu 54. Indeks glikemiks adalah angka yang menunjukkan potensi peningkatan gula darah dari karbohidrat yang tersedia pada suatu pangan atau secara sederhana dapat dikatakan sebagai tingkatan atau rangking pangan menurut efeknya pada kadar glukosa darah.
Indeks glikemiks diklasifikasikan menjadi 3 kriteria, yaitu rendah (kurang dari 50), sedang (55-69), dan tinggi (70 atau lebih). Penggunaan gula yang berbeda dapat memberikan cita rasa minuman coklat dan tingkat penerimaan konsumen yang berbeda pula. Penelitian ini bertujuan untuk mengetahui pengaruh penggunaan gula pasir dan gula kelapa butiran pada tingkat penerimaan minuman coklat.

\section{BAHAN DAN METODE PENELITIAN}

Bahan

Bahan yang digunakan dalam penelitian ini adalah bubuk coklat yang diperoleh dari Kampung Coklat Blitar, gula pasir, gula semut, dan susu skim. Alat yang dibutuhkan untuk pembuatan minuman coklat adalah timbangan, cawan timbang, gelas ukur, panci, kompor, dan aluminium foil. Peralatan yang digunakan dalam pengujian sensoris adalah gelas sloki, sendok teh, nampan, alat tulis, dan borang sensoris.

\section{Metode}

Metode penelitian dibagi menjadi 2 (dua) tahapan yaitu (1) pembuatan minuman coklat dan (2) pengujian sensoris. Tahap pembuatan minuman coklat mengacu pada penelitian (Apriyanti, 2016). Pertama, sebanyak 25 gram coklat bubuk ditimbang kemudian ditambah 12,5 gram susu full cream bubuk, dan 50 gram gula. Seluruh bahan dilarutkan dalam $500 \mathrm{ml}$ air dan dipanaskan pada suhu $85^{\circ}-90^{\circ} \mathrm{C}$ selama 5 menit. Formula A menggunakan gula pasir dan Formula B menggunakan gula kelapa butiran (gula semut). Minuman coklat yang diperoleh kemudian digunakan dalam pengujian sensoris untuk menentukan penerimaan panelis terhadap kedua formula. Formulasi ditampilkan pada Tabel 1. 
Tabel 1. Formulasi Minuman Coklat Menggunakan Gula Pasir dan Gula Semut

\begin{tabular}{|l|l|l|}
\hline Bahan & Formula A & Formula B \\
\hline Coklat Bubuk & 25 & 25 \\
\hline $\begin{array}{l}\text { Susu Full } \\
\text { Cream }\end{array}$ & 12,5 & 12,5 \\
\hline Gula Pasir & 50 & - \\
\hline Gula Semut & - & 50 \\
\hline Air & 500 & 500 \\
\hline
\end{tabular}

Uji sensoris yang digunakan adalah Paired Difference Test dan Acceptance Test. Untuk menentukan ada atau tidaknya perbedaan karakteristik kedua minuman coklat digunakan Paired Difference Test. Pada pengujian ini, Formula A dan Formula B disajikan dalam gelas sloki dengan kode yang berbeda, panelis diminta untuk mencicip kedua sampel. Apabila terdapat perbedaan maka panelis memilih "ada" dan apabila kedua sampel sama maka panelis memilih "tidak ada". Jumlah panelis yang memilih "ada" dan "tidak ada" kemudian ditabulasikan dan dianalisis menggunakan Critical Table for Paired Comparison and Paired Difference Test.

Apabila ada perbedaan yang signifikan, maka dilakukan pengujian kedua yaitu Acceptance Test. Pada tahap ini panelis diminta untuk menentukan formula yang lebih disukai. Berdasarkan atribut-atribut sensorisnya. Atribut sensoris yang diuji adalah gurih, rasa coklat, manis, pahit, dan keseluruhan. Formula yang dipilih bernilai 1 dan yang tidak dipilih bernilai 0. Data yang diperoleh kemudian ditabulasi dan dianalisis.

\section{Analisis Data}

Analisis data Uji Pembedaan menggunakan Tabel Uji Pembedaan, sedangkan untuk Acceptance Test digunakan T-test untuk menentukan ada tidaknya perbedaan nyata antarsampel.

\section{HASIL DAN PEMBAHASAN}

3.1 Tingkat Perbedaan Minuman Coklat

Rasa dipengaruhi oleh beberapa hal, antara lain senyawa kimia, suhu, konsentrasi, dan interaksi dengan komponen lain (Winarno, 1997). Senyawa flavor pada produk memberikan rangsangan pada indera penerima pada saat dimakan. Apabila rangsangan melebihi threshold (ambang rangsangan) maka akan dirasakan oleh penerima dan diterjemahkan sebagai rasa tertentu. Threshold adalah ambang rangsangan terkecil yang dapat dikenali oleh indera perasa. Threshold dibagi menjadi absolute threshold, recognition threshold, difference threshold, dan terminal threshold. Absolute threshold adalah jumlah komponen rangsang terkecil yang mulai menimbulkan kesan.

Recognition threshold adalah jumlah komponen rangsang terkecil yang mulai dapat dikenali jenis kesannya (manis, asam, pahit, dll), difference threshold adalah perbedaan terkecil dari rangsangan yang dapat dikenali atau dibedakan intensitas rangsangnya, dan terminal threshold adalah rangsangan terbesar yang jika dinaikkan sudah tidak dapat meningkatkan intensitas kesan. Apabila intensitas perbedaan dua produk lebih kecil dari difference threshold maka kedua produk dirasakan "sama" oleh panelis sedangkan apabila lebih besar dari difference threshold maka kedua produk dirasakan "berbeda" oleh panelis. Untuk 
mengetahui kedua ada atau tidaknya perbedaan minuman coklat yang dibuat dari gula pasir dan gula kelapa maka dilakukan
Paired Difference Test. Hasil Paired Difference Test ditampilkan pada Gambar 1.

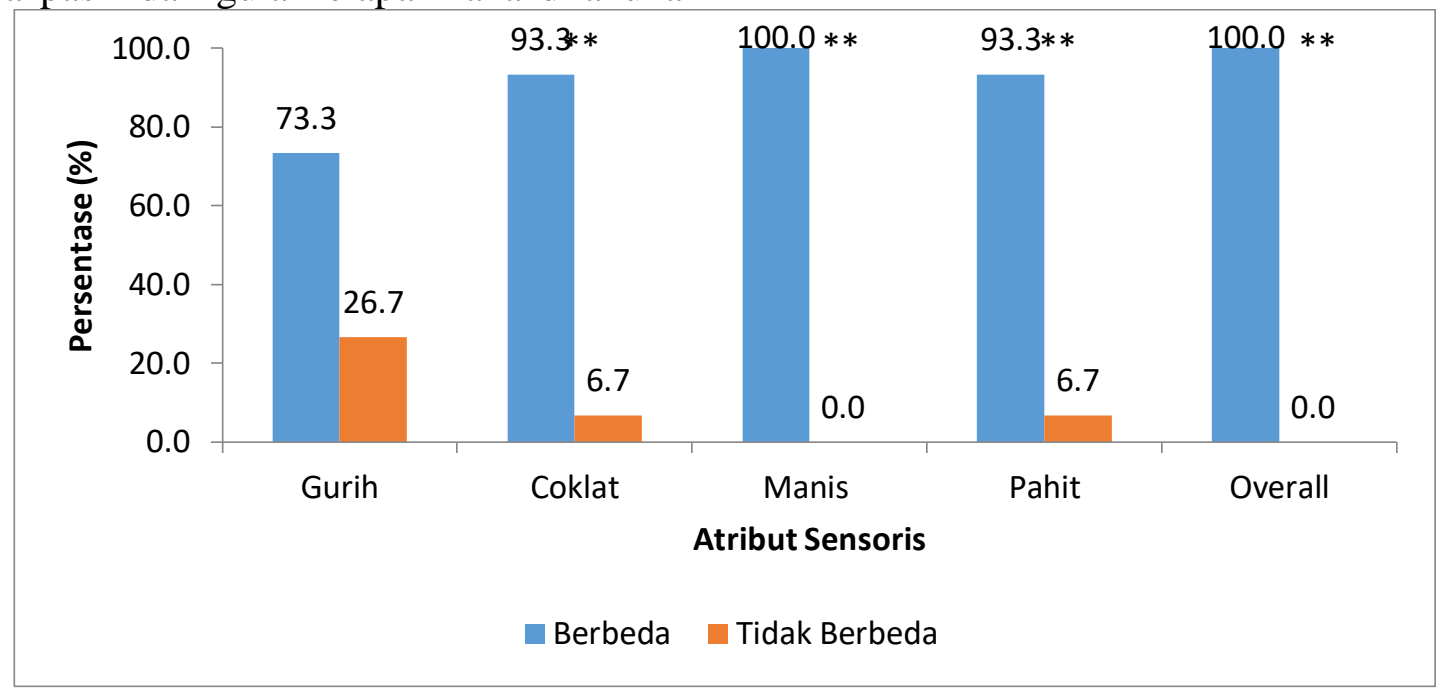

Gambar 1. Hasil Uji Pembedaan Minuman Coklat dengan Gula Pasir (Formula A) dan Gula Kelapa Butiran (Formula B). Hasil pengujian sensoris menunjukkan bahwa penggunaan jenis gula yang berbeda menghasilkan minuman dengan atribut sensoris yang berbeda nyata.

Berdasarkan Tabel Paired Difference Test untuk 15 panelis, produk dinyatakan berbeda nyata jika persentase panelis yang menyatakan berbeda mencapai $80 \%$ (untuk $\mathrm{p}<0,05)$, dinyatakan berbeda sangat nyata 3.

\section{Tingkat Penerimaan Minuman Coklat}

Atribut sensoris utama pada minuman coklat adalah rasa coklat, manis, pahit, gurih dan keseluruhan. Hasil uji penerimaan ditampilkan pada Gambar 2. jika mencapai $87 \%$ (untuk $\mathrm{p}<0,01$ ) dan dinyatakan amat sangat berbeda nyata jika mencapai 93,3\% (untuk p<0,001). Dari hasil diketahui bahwa atribut sensoris tidak berbeda nyata sedangkan rasa coklat, manis, pahit, dan keseluruhan berbeda amat sangat nyata pada kedua produk. Data ini menunjukkan bahwa hampir seluruh panelis dapat merasakan perbedaan produk. Dengan kata lain, gula pasir dan gula kelapa menghasilkan minuman coklat dengan karakteristik yang sangat berbeda nyata. 


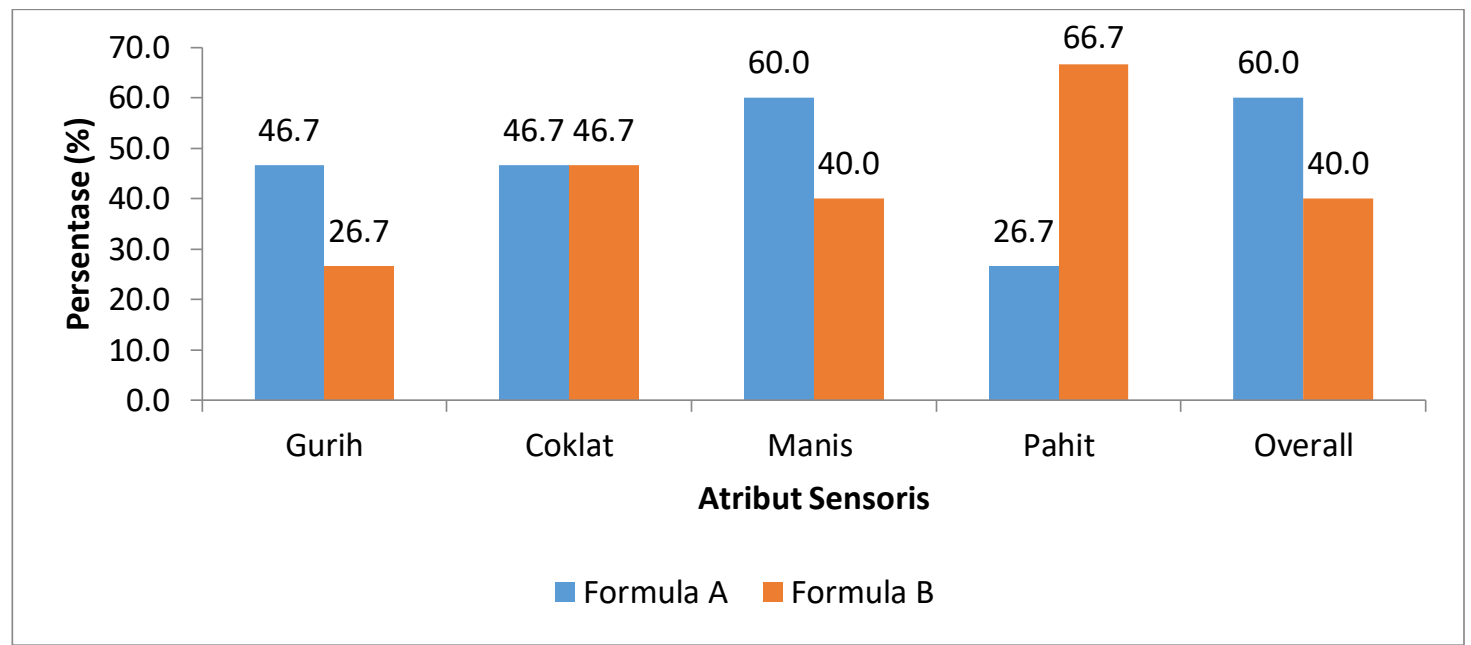

Gambar 2. Hasil Uji Penerimaan Minuman Coklat dengan Gula Pasir (Formula A) dan Gula Kelapa Butiran (Formula B). Hasil pengujian sensoris menunjukkan bahwa penggunaan gula pasir menghasilkan minuman dengan rasa gurih, manis, dan keseluruhan yang lebih bisa diterima oleh panelis.

Pada Gambar 2 menunjukkan bahwa pada atribut sensoris minuman coklat berupa minuman coklat yang dibuat dari gula kelapa. Rasa manis diperoleh dari gula. Gula merupakan karbohidrat golongan sederhana yang biasa digunakan sebagai bahan pemanis. Tingkat kemanisan produk mempengaruhi tingkat penerimaannya. Peningkatan rasa manis dapat meningkatkan penerimaan panelis pada titik tertentu, namun rasa manis yang berlebih justru menurunkan tingkat penerimaan panelis (Butar, 2011).

Gula pasir adalah sukrosa yang tersusun oleh glukosa dan fruktosa. Gula kelapa adalah gula yang dihasilkan dari pengolahan nira kelapa, mengandung sukrosa $68,35 \%$, gula pereduksi 6,5\% (Thampan, 1982), lemak $10 \%$, protein, kalsium, dan fosfor. Dari kandungan ini, maka gula kelapa memiliki komponen penyusun yang lebih beragam dan kandungan gizi yang lebih tinggi dibandingkan gula pasir (Santoso, 1993).

Namun seiring dengan meningkatnya jumlah gula yang diberikan pada masingmasing perlakuan menyebabkan semakin gurih, manis, dan keseluruhan lebih disukai oleh panelis dibandingkan manisnya rasa sirup. Rasa manis yang berlebih ini mempengaruhi penerimaan panelis terhadap rasa sehingga semakin banyak gula yang diberikan semakin berkurang tingkat kesukaan panelis. Dari hasil penilaian panelis saat uji organoleptik secara keseluruhan, dapat disimpulkan bahwa produk yang paling disukai adalah produk B yaitu penambahan gula sebesar $55 \%$ dengan rata-rata skor warna $90 \%$, aroma $75 \%$ dan rasa $75 \%$. 
Gula merah memiliki tingkat kemanisan $10 \%$ lebih tinggi daripada gula pasir. Hal ini dapat disebabkan oleh kandungan fruktosa dalam gula merah yang memiliki nilai kemanisan lebih tinggi dibandingkan sukrosa. Selain itu, gula merah memiliki karakteristik sedikit asam, aroma khas, dan berbau karamel yang diperoleh dari kandungan asam organic (Utami, 2008).

Gula kelapa memiliki karakteristik yang khas yaitu dapat menutupi aroma dan rasa komponen yang lain dalam produk (Rahmah, 2016). Komponen lain di dalam gula kelapa seperti asam malat, asam sitrat, dan asam laktat memberikan rasa yang khas dan menutupi rasa coklat dari produk.

\section{KESIMPULAN}

a. Minuman coklat yang dibuat dengan gula pasir dan gula kelapa memiliki karakteristik yang berbeda nyata, kecuali pada atribut gurih.

b. Minuman coklat dengan gula pasir lebih disukai oleh panelis dibandingkan minuman coklat dari gula kelapa. Selain itu, minuman coklat dengan gula pasir memiliki nilai ekonomis yang lebih tinggi namun memiliki nilai gizi yang lebih rendah daripada gula kelapa butiran.

\section{DAFTAR PUSTAKA}

Apriyanti, Ni Wayan Yeni. 2016. Pengembangan Produk Minuman Coklat Kemasan Siap Saji dengan Pemanis Gula Kelapa Butiran. Skripsi. Universitas Gadjah Mada. Yogyakarta

Butar, Frengki Butar. 2011. Pengaruh Penambahan Konsentrasi Gula Terhadap Kualitas Sirup Mangga Arum Manis Lewat Matang. Skripsi. Politeknik Pertanian Negeri Samarinda. Samarinda

Gunawan, G.A., P.K. Atmodjo, dan B.B.R. Sidharta. 2015. Variasi Kismis dan Sukrosa Terhadap Pertumbuhan Asam Laktat, dan Alkohol Kristal Alga. Fakultas Tekhnobiologi. Universitas Atma Jaya. Yogyakarta

Rahmah, Fani Aulia. 2016. Pengaruh Penggunaan Jenis Gula Merah dan Lama Fermentasi Terhadap Karakteristik Water Kefir. Skripsi. Universitas Pasundan. Bandung

Santoso, H.B. 1993. Pembuatan Gula Kelapa. Kanisius. Yogyakarta

Thampan, P.K. 1982. Handbook on Coconut Palm. Oxford and IBH Publishing Co. New Delhi

Utami, M.F. 2008. Studi Pengembangan Usaha Gula Merah Tebu di Kabupaten Rembang. www.scribd.com. Diakses pada 12 Oktober 2018.

Winarno, F.G. 1997. Pengantar Teknologi Pangan. PT Gramedia Pustaka Utama. Jakarta 